Yüzüncü Y1l Üniversitesi
Tarim Bilimleri Dergisi

Derleme Makalesi (Review Article)

\title{
Nanomateryallerin Tarımda Kullanımı
}

\section{Kağan Tolga CİNISLLI ${ }^{* 1}$, Sevda UÇAR ${ }^{1}$, Neslihan DİKBAŞ ${ }^{1}$}

${ }^{1}$ Atatürk Üniversitesi, Ziraat Fakültesi, Tarımsal Biyoteknoloji Bölümü, 25000, Erzurum, TÜRKIYYE
*Sorumlu yazar e-posta: kagantolgacinisli2525@gmail.com

\section{Makale Bilgileri}

Geliş: 23.07.2019

Kabul: 28.09.2019

Online Yayınlanma 31.12.2019

DOI: $10.29133 /$ yyutbd.595658

\section{Anahtar kelimeler}

Büyüme Düzenleyici,

Gübre,

Nanomalzemeler,

Tarım.
Öz: “'Nano-Era”' adıyla bilinen akım giderek yaygınlaşarak çeşitli nanoteknoloji araştırma programları ve mühendislik uygulamaları ile birlikte son derece popülerlik kazanarak araştırmacıların dikkatini çekmektedir. Tarımda nanomateryallerin kullanımı 'under explorer', olarak adlandırılmaktadır. Nanomateryallerin kendilerine ait üstün özellikleri ile tarımsal uygulamalarda ne düzeyde olumlu katkı yaratabilecekleri merak konusudur. Bu hipotezle çalışma, çeşitli nanomalzemelerin gübre ve büyüme düzenleyici olarak kullanılabilirliği açısından güncel araştırmaları içermektedir. Derleme makale, nanomateryallerin tarımda uygulanması konusunda ilgili araştırmacılar için önemli bir veri kaynağı ve haraket noktası olabilecek düzeyde önem arz etmektedir.

\section{Use of Nanomaterials in Agriculture}

\section{Article Info}

Received: 23.07.2019

Accepted: 28.09.2019

Online Published 31.12.2019

DOI: $10.29133 /$ yyutbd.595658

\section{Keywords}

Growth regulator,

Fertilizer,

Nanomaterials, Agriculture.

\begin{abstract}
The current known as "Nano-Era" is becoming increasingly widespread, gaining extremely popularity along with various nanotechnology research programs and engineering applications, attracting the attention of researchers. The use of nanomaterials in agriculture is called "under explorer". Nanomaterials with their superior characteristics, what order of agricultural applications can create a positive contribution is a matter of wonder. Working with this hypothesis includes current research in terms of the availability of various nanomaterials as fertilizers and growth regulators. The review paper is important for the researchers concerned in the application of nanomaterials in agriculture at a level that may be an important data source and point of action.
\end{abstract}

\section{Giriş}

Gelişen Dünyada, 2000’li y1lların başlarında 35’ten fazla ülkenin nanoteknoloji araştırma programları ve mühendislik uygulamalarında nanomalzemelerin kullanılmasıyla "Nano-era", adıyla bilinen yeni bir akım ortaya çıkmıştır (Roco, 2003). Bu akım giderek yaygınlaşmış hatta nanomalzemelerin tarımda kullanılabileceği öngörüsüyle araştırmacılar bu alanda çeşitli çalışmalara 
başlamışlardır. Boyutu 100 nm'nin altında olan maddeler nano madde olarak adlandırılmış, üretim, işleme taşıma, paketleme ve tarımsal ürünlerin taşınması konusunda kullanılabileceği görülmüştür (Scott and Chen, 2003; Wiesner et al., 2006). Bitki gelişim üzerine farklı nanopartiküllerin etkisi Şekil 1 ' de verilmiştir. Nanomalzemeler tarımda gübre uygulamalarında önemli bir yer edinerek, bitkiyi yavaş yavaş kontrollü bir biçimde besleyebileceği Sohrab et al. (2016) tarafından bildirilmiştir. Nano-gübreler, kimyasal gübrelerin neden olduğu toprak kirliliğinden doğan çevresel risk etmenlerini azaltarak bitki ve doğaya olumlu bir etkide bulunabilir (Naderi et al., 2011). En büyük avantajlarından biri de diğer gübrelere göre daha az miktarda kullanılmasıdır (Selivanov and Zorin, 2001; Reynolds, 2002; Raikova et al., 2006; Batsmanova et al., 2013; Subramanian et al., 2015).

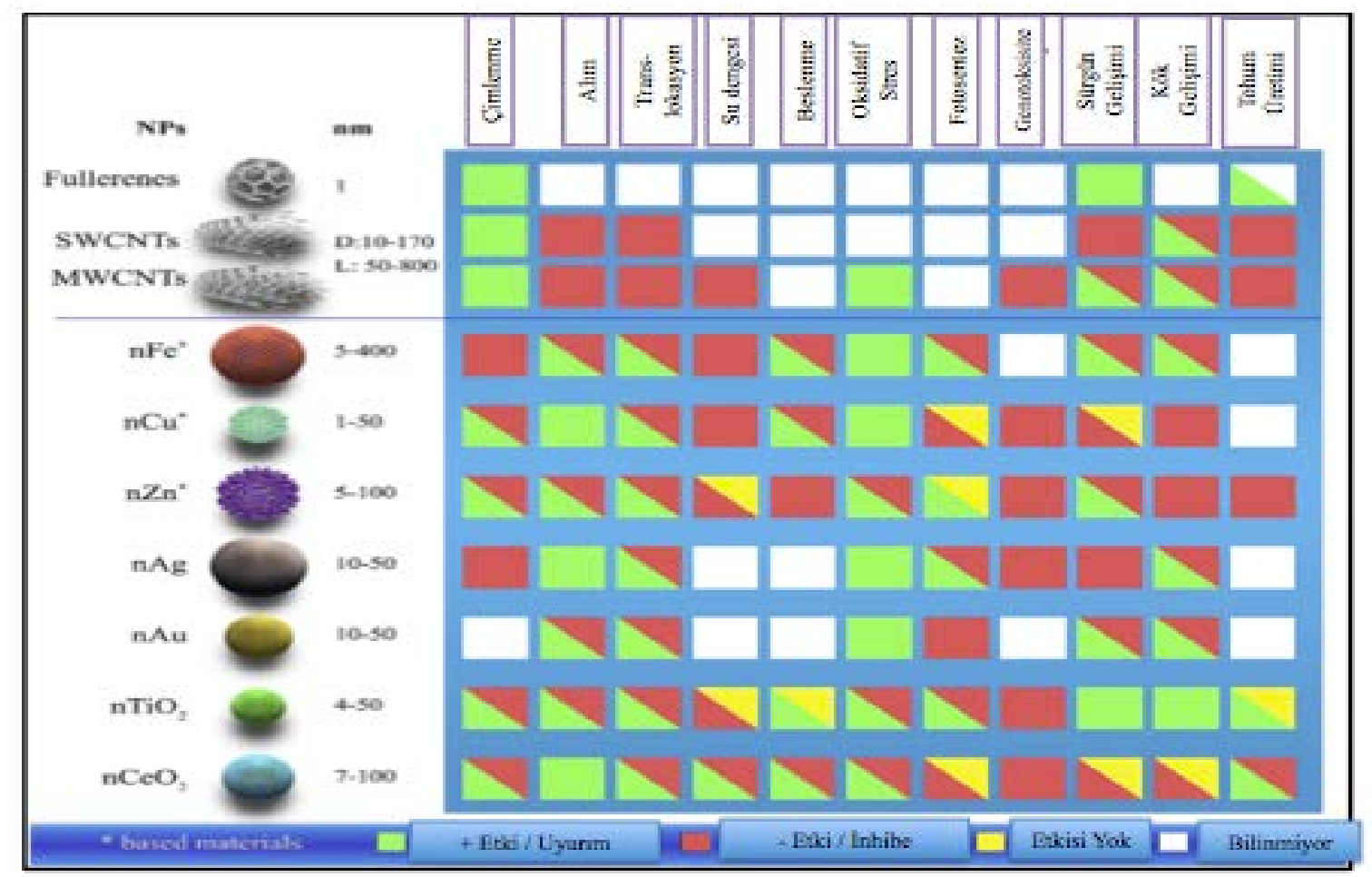

Şekil 1. Çeşitli nanomateryallerin tarımda kullanılması ve bitki gelişimine farklı düzeylerdeki etkileri (Mukherjee ve ark., 2015).

Nano-gübreler konusunda yapılan pek çok çalışmada sahip oldukları geniş yüzey alanlarının yanı sıra bitkilerin yaprak ve kök gözenek boyutlarından daha küçük boyutlara sahip olduklarından temas ettikleri yüzeyden bitkiye geçişleri, besinlerin alımını daha kolay hale getirerek kullanım etkinliğini arttırdıkları belirtilmiştir (Sing ve ark., 2017). Nano-gübrelerin, bitkinin yaşam periyodu boyunca gelişime olumlu katkı sağlamasına yardımcı olmalarının temelinde bitki metabolizmasında yarattığı olumlu etkilerin, enzimsel ve hormonal düzeyde etki mekanizması ile değişken ve şiddetli atmosferik koşullara, biyotik-abiyotik strese ve hastalıklara karşı dirençli hale gelebildiği öne sürülmüştür (Mukherjee ve ark., 2015). Toprakta nanopartikül uygulamalarıyla elverişli ve yeterli miktarda mikro element içeriği bulunabilir, böylece bitkilerin patojenlere karşı direnci de artabilir. Fakat bazı faktörler toprakta bulunan besin elementlerinin bitkiler tarafından alımı üzerinde olumsuz etki yaparak sınırlandırır. Alkalin topraklarda mikro besin elementlerinin bitki tarafından alınabilirliği azalmaktadır. Örneğin; toprak pH'sı bazikleştikçe topraklarda çinko, mangan ve demir biyo yarayışlı1ığı azalmaktadır. Bu elementlerin alımları kökler tarafından sınırlandırılarak bitki enfeksiyona açık hale gelmiş olur (Güneş ve ark., 2007; Servin ve ark., 2015).

Nano-gübrelerin boyutlarının küçük olması, mineralin stomalardan kolaylıkla geçmesine yol açarak bitkinin minerallerden kolayca faydalanmasını sağlarlar (Liu ve Lal, 2016; Sing ve ark., 2017). Böylelikle uygulanmış gübrelerden maksimum verim alınabileceği Liu and Lal, 2016 tarafından bildirilmiştir. Nano-gübrelerin geleneksel gübrelere göre, birçok avantajaları vardır (Liu ve Lal, 2016; Sing ve ark., 2017; Dağhan, 2017, Ahmad, 2019). Bu avantajların bazıları; gübreyi çok az miktarda 
kullanarak en düşük maliyetle en yüksek verimin alınabilecek olması, halihazırda olan besinin bitkide kullanım verimliliğini arttırması, gübre kullanım etkinliğinin arttırılması, sürekli gübre kullanılmasının önüne geçilmesi, bitkiler için yararlı olan besinlerin kayıplarını azaltarak çevre üzerine olası olumsuz etkilerinin minimize edecek olması, toprak muhtemel oluşacak toksisite riskini azaltılıp, toprak verimliliğinin ve ürün kalitesinin arttırılması olarak sıralanabilir. Nano-gübreler bitkinin yetişme periyodu boyunca sağliklı olarak gelişme ve büyümesini imkan sağlayarak ürün verimi ve besin değerini arttırırlar. Böylelikle sağlıklı olan bitki hastalıklara ve olumsuz çevre koşullarına karşı daha fazla direnç kazanması açısından nano-gübreler önemlidir (Dağhan, 2017).

Nano-gübrelerin pek çok üstün özelliklerine rağmen bazı olumsuz etkileri de bulunmaktadır. Nano boyuttaki partiküller sağlığa ve çevreye karşı bazı riskler barındırmaktadır. Nano-malzemelerle ilgili yapılan ilk çalışmalarda, insanlar üzerinde toksik etkilere neden olduğunu göstermiştir. Nanopartiküller insan vücuduna girerek tüm hayati organlara ulaşıp dokularda zararlara neden olabilmektedir (Dağhan, 2017). Literatür bilgisine göre nano-gübrelerin toksik etkilere de sahip oldukları, ekosistem için önemli problemlerin oluşmasında etken ve oluşturdukları çevre sorunlarının onarımının oldukça güç olduğu bildirilmiştir (Dağhan, 2017).

Bu derleme çalışmasının amacı; tuz stresinden kaynaklanan bitkisel ürün kaybının nanopartiküler çinko ve mikrobiyal sentez formülasyonu kullanılarak biyoteknolojik yöntemlerle azaltılması yönünde gübre formülasyonlarının oluşturulmasıdır. Böylelikle, muhtemelen üretici mikrobiyal gübre ve nanogübre adı altında pahalı gübreleri ayrı ayrı almak yerine oluşturulacak gübre formülasyonunun tek bir ürün olarak kullanılabilirliği denemelerle araştırılmıştır.

\subsection{Bazı Nanopartiküllerin Bitkiler Tarafından Alım Formları}

Nanopartiküller (NP), bitki besin elementlerini şu üç yoldan biriyle bitkiye iletirler; 1) Besin elementi, nano-tüpler veya nano gözenekli malzemeler gibi nanomalzemeler içine kapsüllenebilir, 2) ince bir koruyucu polimer film ile kaplanır veya 3) nano ölçekli boyutlardaki partiküller veya emülsiyonlar halinde bitkiye taşınırlar (Nair et al., 2010). Nano-gübre formülasyonlarındaki nanopartiküller'in boyutları, hücre duvarı gözeneklerinden küçükse, direkt bitki hücrelerine girmesi mümkündür. Ancak NP'lerin daha ileri aşamaları hücre zarı, besin maddelerinin sitoplazma ile etkileşimleri incelemenin ötesinde ve NP taşınım mekanizması çok karmaşıktır (Nair et al. 2010). Bununla birlikte, besin elementleri su/toprak çözeltisinde nanoparçacık çözülmesi yoluyla bitki kökü sistemi tarafından absorplanmaktadır. Başka bir deyişle, NP'ler suda çözülür ve besin maddelerini çözünmüş iyonlar halinde serbest bırakır (Denklem 1-3). Bitkiler ayrım gözetmeden besleyici çözünmüş iyonları konveksiyonel gübrelerden alabilir. Ancak, su/toprak çözeltisindeki NP'lerin çözünme hızı ve kapsamı, yüksek spesifik yüzey alanları ve boyutları ilgili katı yüzeylerden daha yüksek olmasından dolayı konveksiyonel gübrelere göre daha etkin bir işleve sahip olabilirler (Ma et al., 2010; Nair et al., 2010; Lin et al., 2008;).

\subsection{Nanopartiküler Makro Besin Elementi İçeren Gübrelerle Yapılan Çalışmalar}

\subsubsection{Nanopartiküler fosfor $(P)$ içeren gübreler}

Liu and Lal (2014) yaptığı çalışmada $16 \mathrm{~nm}$ boyutlarında yeni bir hidroksiapatit türü $\left(\mathrm{Ca}_{5}\left(\mathrm{PO}_{4}\right)_{3} \mathrm{OH}\right)$ NP'ler sentezleyerek sera denemesi ve atıl büyüme ortamında NP'lerin \%50 perlit ve $\% 50$ turba yosunu ortamında yetiştirilen soya fasulyesi üzerindeki gübreleme etkisini değerlendirmişlerdir. Çalışma sonucunda elde edilen veriler $\left(\mathrm{Ca}\left(\mathrm{H}_{2} \mathrm{PO}_{4}\right)_{2}\right)$ NP'lerin uygulanmasının büyüme oranını ve tohum gelişimini sırasıyla $\% 33$ ve $\% 20$ oranlarında arttırdığını tespit edilmiştir. Biyokütle üretimi, yerüstü aksam için sırasıyla $\% 18$ ve yeraltı aksamlar için $\% 41$ oranında artırılmıştır. Veriler, soya fasulyesinin köklerinin hidroksiapatit NP'leri etkin bir fosfor besin kaynağı olarak emebileceğini ve sağlıklı büyümeyi ve yüksek verim sağlayabileceğini göstermiştir. Aynı zamanda fosfora ek olarak, NP'ler bitkilere besin Ca da sağlayabileceği tesbit edilmiştir. Apatit NP'leri yeni bir P sınıfı gübre olarak kullanmak, tarımsal verimliliği potansiyel olarak artırabileceği, NP'ler sayesinde fosforun mobilizasyonunun geleneksel fosforlu gübrelere göre azalmasiyla ötrifikasyon riskini engelleyebileceği ortaya konmuştur. Örneğin, apatit NP'ler yüklü $\mathrm{PO}_{3}{ }^{4}-, \mathrm{HPO}_{4}{ }^{2}-, \mathrm{H}_{2} \mathrm{PO}^{4}-$ veya $\mathrm{Ca}_{2}{ }^{+}$ iyonlarına kıyasla zemin bileşenleri ile çok daha zayıf etkileşime sahiptir. Bu nedenle, NP'lerin önemli 
bir kısmı köklerin emilmesi için toprak çözeltisinde kalır. Geleneksel fosforlu gübreler ise NP'lere göre yüklü fosfat iyonlarının çoğu toprak parçacıkları tarafından absorbe edildiği için bitkiler tarafından alımı azalır (Liu ve Lal 2014). Buna ek olarak, apatit NP'ler çözünebilir fosfat iyonlarına göre daha az biyolojik olarak bulunabilir ve ötrofikasyon açısından düşük riskler oluşturabilir. Apatit NP'lerin, toprak parçacıklarıyla olan etkileşimleri, toprak gözeneklerindeki taşınım, alglerin biyo-yararlılıkları ve tarla koşullarında ürün tepkisi üzerine diğer düzenli fosfor gübrelerine kıyasla bu potansiyel yararlarını teyit etmek için ek araştırmalara ihtiyaç duyulmaktadır.

\subsubsection{Nanopartiküler kalsiyum (Ca) içeren gübreler}

Liu ve ark. (2005) tarafından Hoagland çözeltisi ile kumda 80 gün boyunca yetiştirilen fistık

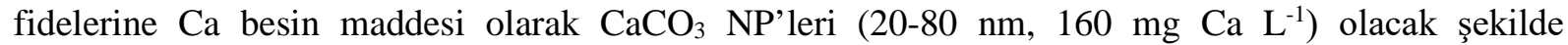
uygulayarak, Ca-NP'lerin fide büyümesini kontrol'e kıyasla önemli ölçüde geliştirdiğini gözlemlemişlerdir. Ca kaynağı olarak kullanılan Ca-NP'leri kök gelişimini sırasıyla \%3.04 ve \%1.58 arttırdığı gözlemlenmiştir.

Liu ve ark. (2005) aynı zamanda Ca-NP'ler ve hümik asitlerin (1.000 $\mathrm{mg} \mathrm{L}^{-1}$ ) birlikte uygulanmasının fıstık fidelerinde maksimum büyümeyi sağladığını bildirmişlerdir. Bu çalışma CaNP'lerin tarla bitkileri için Ca içeriği açısından büyük bir potansiyeli olduğunu göstermiştir.

\subsubsection{Nanopartilküler magnezyum (Mg) içeren gübreler}

Delfani ve ark. (2014) bezelyede Mg-NP ve Fe-NP eriyiklerinin yapraktan uygulanmasını test etmişler ve $0.5 \mathrm{~g} \mathrm{Mg}-\mathrm{NP}$ ve Fe-NP L ${ }^{-1}$ kombinasyonunun 1.000 tane ağırlığına $\% 7$ oranında ağılık artış1 sağlayarak, klasik Fe ve $\mathrm{Mg}$ uygulamalarından yüksek olduğunu gözlemlemişlerdir. Söz konusu çalışmada bu iki elementin yapraktan uygulanmasının bitkinin fotosentez miktarını arttırdığı gözlenmiştir. Fakat Mg-NP uygulaması yalnız başına verimliliği kontrole göre \%6 oranında düşürmüştür. Ancak, araştırmacılar Mg NP'lerin uygulanmasının bitki sapları ve yapraklarında düzenli $\mathrm{Mg}$ tuzu kullanımıyla karşılaştırıldığında Mg alımını geliştirdiğini ve Mg-NP’lerin daha yüksek kullanılabilirlik ve hareketliliğini gösterdiğini gözlemlemiş̧lerdir.

\subsection{Nanopartiküler Mikrobesin Elementli Nano-Gübrelerle Yapılan Çalışmalar}

Genellikle bitki beslenmesinde rol alan önemli mikro besin maddeleri, demir ( $\mathrm{Fe}$ ), çinko (Zn), mangan (Mn), bakır (Cu), bor (B), klor (Cl) ve molibden (Mo)'dir. Mikro besin elementleri makro besin maddeleri (N, P, K, Ca, Mg ve S) ile karşılaştırıldığında, Hoagland çözeltisinin bileşiminde gösterildiği gibi, bitki ve diğer bitkilerin sağlıklı bir şekilde büyümesi için daha az miktarda mikro besin maddesi gereklidir (Hoagland ve Arnon 1950). Ancak bitkiye yarayışlılık konusunda mikrobesin elementlerinin yarayışlılığını azaltan durumlar (kaba tekstür, alkalilik, düşük organik madde vb.) vardır. Bu kötü durumlara karşı mikrobesinlerle nano-gübreleme bu besinlerin biyolojik olarak kullanılabilirliğini arttırir.

Mikrobesinler, çoğunlukla N, P ve K içerikli gübrelerin etkin alımı için düşük oranlarda çözünebilir tuzlar olarak ilave edilir. Bu kompozit gübrelerde bulunan mikro besinler genellikle yeterli besin sağlar ve çevresel riskleri az etkiler. Mikro besin maddesi içeren NP’lerin, mikrobesinli nano-gübreleme konusunda araştırma ve geliştirme yapmak için bazı temel bilgiler besin maddelerinin bitki gelişimini artırabileceği öngörülmektedir (Mahajan ve ark., 2011).

\subsubsection{Nanopartiküler demir (Fe) içeren gübreler}

Ghafariyan ve ark. (2013) tarafindan yapılan bir sera denemesinde, süper paramanyetik FeNP'lerin düşük konsantrasyonlarının bile hidrofobik koşullar altında, soya fasulyesi yapraklarındaki klorofil içeriğini önemli ölçüde arttırdığını bildirmişlerdir. Böylelikle Fe-NP’lerin soya fasulyesinde demir kaynağı olarak kullanılabilir ve demir eksikliğinin klorotik belirtilerini azaltabileceği gösterilmiştir. Fe-NP’lerin $45 \mathrm{mg} \mathrm{L}^{-1}$ konsantrasyonundaki kullanma etkisi Fe-EDTA’nın aynı dozdaki kullanım etkisinin bitkiye yaptığı etkilerinin benzer olduğu gözlenmiştir. Delfani ve ark. (2014), bezelyede yaptıkları çalışmada $500 \mathrm{mg}$ Fe-NP'ler $\mathrm{L}^{-1}$ 'nin yapraktan uygulamasının, bitki başına bakla 
sayısını (\%47 oranında), 1.000 tane ağırlı̆̆ında (\%7 oranında), Fe içeriğini (\%34 oranında) ve klorofil içeriğini (\%10 oranında) ise kontrole göre arttırdığını tespit etmişlerdir. Fe-NP'lerin uygulanması ile elde edilen ürün performansı, Fe tuzu ile elde edilen ürün performansından daha fazla olmuştur. Fe-NP muamelesi altında olan bitkilerde sırasıyla $\% 28, \% 4, \% 45$ ve $\% 12$ artmıştır.

\subsubsection{Nanopartiküller Çinko (Zn) İçeren Gübreler}

ZnO-NP'ler yıllardır endüstride en çok kullanılan metal oksit nanopartiküllerinden biridir. Böylece, Zn-NP'lerin bitkiler ve diğer organizmalar üzerindeki etkileri yoğun olarak incelenmektedir. Mahajan ve ark. (2011) tarafindan bitki agar yöntemini kullanarak, ZnO-NP'lerin düşük konsantrasyonlarda fasulye ve nohut fidelerinin büyümesini arttırdığını gözlemlemişlerdir. Fasulye fidelerinin kökleri için en iyi büyüme tepkisi (uzunlukta $\% 42$ veya $\% 41$ artış, biyokütlede $\% 98, \% 76$ ), kontrol grubunda $20 \mathrm{mg} \mathrm{L}^{-1}$ konsantrasyonunda gözlenmiştir. Nohut fideleri için $1 \mathrm{mg} \mathrm{L} \mathrm{L}^{-1}$ konsantrasyonunda, kökte (\%53) biyokütlede (\%37) ve sürgünde uzunluk (\%6) oranında önemli artışlara neden olmuştur. Bununla birlikte, kök ve sürgünlerin büyüme hızlarındaki düşüş, bu optimal konsantrasyonların ötesinde gözlenmiştir.

Zhao ve ark. (2013) tarafından yapılan bir sera çalışmasında, bir toprak karışımına 400 ve 800 mg ZnO-NP kg-1 uygulanmasının salatalık biyokütlesini arttırdığı bildirilmiştir. Sonuçlar, meyvelerin kuru ağırlığının, kontrol grubuna kıyasla sadece $\% 6$ ve $\% 8$ oranında artmasına rağmen, bitki kökü kuru kütlesinin kontrol grubuna göre 1,1 ve 1,5 kat daha yüksek olduğunu ortaya koymuştur. Hasat edilmiş salatalık meyvelerinde, ZnO-NP'lerin uygulanması da, nişasta içeriğini (1.1-1.6 kat), glutelin (0.9-2 kat) ve Zn’yi (1.7-2.5 kat) arttırdığını bildirmişlerdir (Zhao ve ark., 2013). Lin ve Xing (2007), 2 mg ZnONP $\mathrm{L}^{-1}$ uygulanmasının çimlendirilmiş turp tohumlarının kök uzamasını kontrole göre arttırdığını bildirilmişlerdir. Optimum konsantrasyonlarda Zn-NP'lerin kullanılması bu fideler üzerinde önleyici veya toksik etkilere sahiptir. Bununla birlikte, bu raporların hepsinde ZnO-NP'lerin ciddi fitotoksisitesi, 400 ile $2000 \mathrm{mg} \mathrm{L}^{-1}$ arasındaki yüksek NP-Zn konsantrasyonlarında olduğu anlaşılmıştır (Lee ve ark., 2010; Lin ve Xing, 2007; Lopez-Moreno ve ark., 2010; Zhao ve ark., 2014).

\subsubsection{Nanopartiküler manganez (Mn) içeren gübreler}

Pradhan ve ark..(2013), metalik Mn-NP’lerin piyasada bulunan $\mathrm{MnSO}_{4}$ tuzundan daha iyi bir mikrobesin elementi olduğunu bildirmişlerdir. Aynı araştırmacılar Mn-NP’lerin fasulye büyümesini ve fotosentez oranını arttırdığını gözlemlemişlerdir. Diğer bir çalışmada fasulye fideleri, büyütme odaları içinde Hoagland çözeltisiyle birlikte perlit ortamında 15 gün inkübe edilmiştir. Litrede $0.05 \mathrm{mg} \mathrm{Mn}$ NP'lerin uygulanması ile kontrole kıyasla kök uzunluğu (\%52), sürgün uzunluğu (\%38), köklenme sayısı (\%71) ve maksimum büyüme artışı sağlanmıştır. Taze biyokütle ve kuru biyokütle de $\mathrm{MnSO}_{4}$ tuzu ile muamele edilen fideler ile karşılaştırıldığında, bu parametreler sırasıyla $\% 2, \% 10, \% 28, \% 8$ ve \%100 Mn-NP'lerin kullanımı ile arttırılmıştır. İlginç bir şekilde $\mathrm{MnSO}_{4}$ uygulaması, $1 \mathrm{mg} \mathrm{L}{ }^{-1}$ konsantrasyonunda bitki büyümesi üzerinde inhibe edici bir etki sergilerken, Mn-NP’lerin uygulanmasıyla bu seviyede hala pozitif bir etki seyrettiğini bildirmiştir. Bitkiler, sağlıklı bir büyüme için toprak çözeltisinde genellikle $0.5 \mathrm{mg} \mathrm{Mn} \mathrm{L}^{-1}$ konsantrasyonuna ihtiyaç duyarlar.

\subsubsection{Nanopartiküler bakır (Cu) içeren gübreler}

Bir tür su otunda (Elodea densa) kullanan 3 günlük inkübasyon çalışması sonucunda, $\mathrm{Cu}$ NP'lerin düşük konsantrasyonlarının $\left(0.25 \mathrm{mg} \mathrm{Cu} \mathrm{L}^{-1}\right)$ bitki fotosentez hızını kontrol grubuna kıyasla \%35 oranında arttırdığını göstermiştir (Nekrasova ve ark., 2011). Shah ve Belozerova (2009), metalik NP-Cu (130 ve $600 \mathrm{mg} \mathrm{kg}^{-1}$ ) ile değiştirilen toprağın, 15 günlük marul fide büyümesini, sırasıyla $\% 40$ ve \%91 oranında önemli ölçüde arttırdığını bildirmiştir. Ancak, yüksek konsantrasyonlarda (200-1.000 $\mathrm{mg} \mathrm{L}^{-1}$ ) metalik NP-Cu, fasulye, buğday (Triticum aestivum) ve sarı kabağın (Cucurbita pepo subspecies) fide gelişimi üzerine toksik etkileri gözlemlenmiştir (Lee ve ark., 2008; Musante ve White, 2012). Stampoulis ve ark. (2009), 1.000 mg metalik Cu-NP L ${ }^{-1}$ uygulamasının, kabakların biyolojik kütlesini Hoagland çözeltisinde 14 gün süreyle uyguladıktan sonra, kontrole göre $\% 90$ düşürdügünü bildirmiş̧ir. Bununla birlikte, bitki büyümesi için optimal sulu $\mathrm{Cu}$ konsantrasyonu sadece $0.02 \mathrm{mg} \mathrm{L}^{-1}$ olup, yüksek $\mathrm{Cu}$ seviyelerinde fitoksisite ortaya çıkabileceği bildirilmiştir. 


\subsubsection{Nanopartiküler molibden (Mo) içeren gübreler}

Batsmanova ve ark. (2014) tarafindan nohutta molibden mikrobesin kaynağı olarak Mo-NP’ler çözeltisi kullanılmasını esas alan bir çalışma yapılmıştır. Tınlı topraklarda nohut tohumları ekiminden önce dört grup (su, Mo-NP'ler, azot bakterileriyle mikrobiyal inkübasyon ve mikroorganizmaların bir kombinasyonu) oluşturulmuştur. Ortalama 1-2 saat olacak şekilde ayrı ayrı inkübasyona tabi tutmuştur. Nohut rizosferinin kapsamlı bir mikrobiyolojik testi yapılarak, dördüncü uygulamanın 'agronomik açıdan değerli' mikroorganizmalarla hemen hemen tüm grupların gelişmesini kontrole göre iki ile üç kat arttırdığını göstermiştir. Bu sonuçlar aynı zamanda bitki başına kök sayısı ve nodül kütlesinin kontrol grubu için 20 kat ve 8 kat fazla olduğu gözlenmiştir.

Nohutta yapılan bir çalışmada Mo-NP uygulanmasının nohudun gelişim parametreleri üzerine direkt faydaları gözlemlenmiştir. Örneğin, bu uygulamayla bitki başına nodüllerin sayısı ve kütlesi sırasıyla kontrollerden 10 ve 6 kat daha fazla olmuştur. Ayrıca, kontrol ile karşılaştırıldığında, $10 \mathrm{mg} \mathrm{L}^{-1}$ gibi konsantrasyona sahip tüm Mo-NP uygulamaları, nohutta bir antioksidan enzimin aktivitesini 2-3 kez, bitki patojenlerine direncin arttığının bir göstergesi olmuştur. Bu nedenle, Mo-NP'lerin tek başına veya mikrobiyal tedavi ile birlikte uygulanması, baklagilin ve diğer ürün türlerinin performansını, verimini ve hastalık direncini artırabilir. Normal metabolizma için bitkiler genellikle toprak çözeltisinde $0.01 \mathrm{mg}$ Mo L ${ }^{-1}$ konsantrasyonuna ihtiyaç duyarlar (Batsmanova ve ark., 2014).

\subsection{Nanomalzemelerle Güçlendirilmiş Gübreler}

NM ile güçlendirilmiş gübreler, bitki besin maddeleri ile zenginleştirildiğinde, besin maddelerinin bitki alım etkinliğini artırabilecek ve/veya geleneksel gübre uygulamasının olumsuz etkilerini azaltabilecek olan nanomalzemeler olarak tanımlanır. Bu NM'ler hedeflenen besin maddelerini içererek bitkiye ulaşmasını sağlar. Bu tipin en önemli örneği, besin artırıcı-zeolitlerdir.

\subsubsection{Nano yapılı zeolit materyali}

Zeolit parçacıkları genellikle nano ölçeklerde görülmez. Fakat zeolitlerin $\mathrm{SiO}_{4}$ ve $\mathrm{AlO}_{4}$ tetrahedranın 3 boyutlu çerçevesinde Al ve Si'nin düzenlenmesi, nanometre (0.3-10 nm çap) içindeki kanallar ve boşlukların oluşmasına neden olur (Ming ve Allen, 2001). Bu nedenle, zeolitler, nano-yapılı materyallerdir. Benzersiz nano gözenekli özelliklerinden dolayı, zeolitler genellikle çok yüksek spesifik yüzey alanı, yüksek katyon değişim kapasitesine sahiptirler ve bitki makro besin maddeleri $\left(\mathrm{K}^{+}\right.$ve $\left.\mathrm{NH}^{+4}\right)$ yönünden oldukça seçicidirler. Bu temel elementler zeolit değişim yüzeyleri boyunca değiştirilebilir, böylelikle bitki yetiştirme için besin maddeleri yavaş yavaş serbest bırakılabilir. Bu nedenle bu besinlerin yeraltı suyuna taşınması ve çevre kirliliği riskleri azaltılır. Dahası, gaz halindeki azotun $\left(\mathrm{NH}_{3}\right.$, $\mathrm{N}_{2}$ veya $\mathrm{N}_{2} \mathrm{O}$ ) buharlaşması da azaltılabilir, çünkü adsorbe olan $\mathrm{N}$, toprak mikroorganizmaları ile amonifikasyon süreci için kullanılamaz. Zeolitlerin bitki besin maddeleri ile yüklenmesi yeni bir kavram değildir ve 1970'lerden beri yoğun bir şekilde incelenmiştir (Ming ve Allen, 2001).

Fakat besinlerce zenginleştirilmiş zeolit gübreler birçok laboratuvar ve tarla örneği üzerinden test edilmiş ve kanıtlanmış nadir nanomalzemedir. Şimdiye kadar zeolitler, azot kullanım verimliliğini artırmak, besin kayıplarını azaltmak ve çevresel riskleri azaltmak için halen ideal bir alt-tabaka halindedir. İlgilenen okuyucular için bazı besin artırımlı zeolit gübrelerinin tarımda kullanılmasının yararlarını gösteren bazı saha çalışmaları Ming ve Allen (2001) tarafindan detaylı bir şekilde yapılmaktadır. Azot kullanımı verimliliği, $\left(\mathrm{NH}_{4}\right)_{2} \mathrm{SO}_{4}$ ile uygulanan toprakların \%30-76'sına kıyasla, 42 günlük bitki büyümesinden sonra $\mathrm{NH}_{4}$-zeolit ile değiştirilmiş topraklarda \%72-95 arasında değişmiştir. MacKown ve Tucker (1985) tarafından yapılan çalışmada, 30 ton $\mathrm{h}^{-1} \mathrm{NH}_{4}$ ile değiştirilmiş zeolit açısından zengin tüf kullanıldığında, nitrifikasyon oranlarının bir tınlı kumda $\% 11$, siltli kil tınında $\% 4$ oranında azaldığını bildirmiştir. Azaltılmış nitrifikasyon oranları, zeolitin $\mathrm{NH}_{4}^{+}$'ün tutulması ve dolayısıyla $\mathrm{NH}_{4}^{+}$'ün nitrifikasyona uğramış bakteriler tarafından dönüştürülmesinden kaynaklanmaktadır. Malekian ve ark.. (2011) $\mathrm{NO}_{3}-\mathrm{N}$ sızıntı suyu ve mısır gelişimine zeolit değişikliğinin etkilerini incelemek için lizimetrik deneyler uygulayarak, 60 kg'lık bir değişikliğin, kontrol için $18 \mathrm{~kg}^{\prime} l 1 \mathrm{k} \mathrm{ha}{ }^{-1}$ 'den $13.8 \mathrm{~kg}^{\prime} l 1 \mathrm{k}$ bir ha ${ }^{-1}$ 'e kadar \%22 oranında azot sızıntısını azalttığını bildirmiştir. Buna ek olarak, hububat verimi $\left(5.907 \mathrm{~kg} \mathrm{ha}^{-1}\right)$ ve kuru yük $\left(10,361 \mathrm{~kg} \mathrm{ha}^{-1}\right)$, kontrole göre 
sırasıyla \%4.9 ve \%10.3 artmıştır (5.631 ve $9.393 \mathrm{~kg} \mathrm{ha}^{-1}$ ). Ayrıca, zeolit uygulaması ile ürünün beslenme etkinliği \% 77.4'ten \%85.8'e yükselmiş olduğuna dikkat çekmişlerdir.

\subsubsection{Doğal olarak bazı besin elementlerini taşıyıcı nanopartiküller}

Bazı laboratuvar deneylerinde, NP'lerin (silis, Fe oksitler, C kaplı demir ve polimerler vb.) bitki dokularına/hücrelere girebileceği ve doku/hücrelerde DNA ve kimyasalların taşınmasına rol oynayabileceği belirtilmiştir (Ghafariyan ve ark., 2013; Liu ve ark., 2002). Bu tür çalışmalar, bu NP'lerin bitki besleme konusunda yeni bir teknik olarak kullanılabileceğini, bitkilere besin maddeleri verebileceği hipotezini geliştirmiştir. Bununla birlikte, bu yaklaşımın, gübre kullanımının etkinliğini arttıran ya da çevresel bozulma risklerini azaltmak için kullanılan geleneksel yöntemlere göre avantajlarının kanıtlanması için kesin bir kanıt bulunmamaktadır. Örneğin, bitkiler doğal olarak kök sistemleri yoluyla toprak çözeltilerinden çözünür besin maddelerini (N, $\mathrm{P}$ ve $\mathrm{K}$ gibi) emebildiğinden büyümelerini arttırmak için bitki dokularına besin yüklü NP'leri enjekte etmek gerekli olabilir. Bu asal NP'ler aracılığıyla bitkilere yeni besin madde aktarma yaklaşımının araştırılmasını ve uygulanmasını desteklemek için daha kuvvetli ve özel çalışmalar gerekmektedir (Ming ve Allen, 2001).

\subsection{Bitki Gelişimini Teşvik Edici Diğer Nanopartiküller}

Diğer bazı nanopartikül türlerinin bitki gelişimine olumlu etki yapan önemli besin elementlerini içermemesine rağmen, bitki büyümesini bir dereceye kadar geliştirebileceğini gösteren birkaç rapor bulunmaktadır. $\mathrm{Bu}$ çalışmaların bazıları $\mathrm{TiO}_{2}$ nanopartiküller (Ti-NP’leri) ve karbon nanotüpler (CNT’ler)'dir (Yang ve ark., 2007).

\subsection{Nanopartiküler Titanyum Dioksit İçeren Gübreler}

Bitkilere mutlak gerekli veya bazı bitkilere yararlı besin elementleri arasında titanyum yoktur. Diğer bir ifade ile titanyum bitki beslemede olmazsa olmaz bir besin maddesi değildir. Çoğu toprakta genellikle \%0,1-\%0,9 arasında değişen yüksek Ti seviyeleri ve toprak çözeltisinde ortalama $0,03 \mathrm{mg}$ Ti $\mathrm{L}^{-1}$ bulunur (Kabata-Pendias ve Pendias, 1984). Ancak, Ti-NP uygulamasının (güneş 1şığına maruz kalma üzerine) bitki-fotosentezinin etkinliğini artırabileceğini; bitki-enzim aktivitesini arttırabileceği ve havada $\mathrm{N}_{2}$ 'nin kimyasal olarak fiksasyonu ile bitkilere daha fazla $\mathrm{N}$ besin sağlayan bitki büyümesini dolaylı olarak arttırabileceğine ilişkin bulgular vardır (Yang ve ark., 2007; Gao ve ark., 2008; Su ve ark., 2009).

Örneğin, Yang ve ark. (2007) 1spanak (Spinacia oleracea) tohumlarını $2.5 \mathrm{~g}$ Ti-NP L ${ }^{-1}$ solüsyonunda 2 gün süreyle ıslatmışlar ve bunları inert bir büyüme ortamında ekmişlerdir. Çözelti, daha sonra çimlendirilmiş fidanlar üzerinde 35 gün boyunca haftada bir kez bir serada yapraklara püskürtülmüştür. Sonuçlar, bitkilerin taze ve kuru ağırlıklarının, kontrollere oranla $\left(\mathrm{TiO}_{2}\right.$ olmadan veya toplu $\mathrm{TiO}_{2}$ muamelesi ile) yaklaşık 2 kat fazla olduğunu göstermiş̧ir. Yapraklardaki toplam N, klorofil ve protein içerikleri sırasıyla $\% 23, \% 34$ ve $\% 13$ artış göstermiştir.

Gao ve ark. (2008) tarafından yapılan çalışmalarda da benzer sonuçlar gözlemlenmiştir. Uygulamalar on kat daha düşük $0.3 \mathrm{~g}$ Ti-NP $\mathrm{L}^{-1}$ konsantrasyonunda gerçekleştirilmiş̧tir. Song ve ark. (2012), 7 günlük bir sürede $0.5 \mathrm{~g} \mathrm{~L}^{-1}$ Ti-NP'lerin fasulye (Lemna minor)'nin uzamasın1 2,5 kattan fazla ve taze ağırlı̆̆ 1 da 2 kat arttırdığını bildirmişlerdir. Benzer şekilde düşük konsantrasyonlarda bir $\mathrm{SiO}_{2}$ ve $\mathrm{TiO}_{2}$ NP'ler karışımı, soya fasulyesinin rizosferinde nitrat redüktaz aktivitesini arttırdığı ve dolayısıyla soya fasulyesinin çimlenmesi ve büyümesini hızlandırdığını bildirmişlerdir (Lu ve ark., 2002). $\mathrm{TiO}_{2}-\mathrm{NP}$, morötesi 1şın altında etkili bir foto-katalizör olup, organik bileşiklerin ayrışması ve güneş enerjisi kullanılarak bir yakıt olarak $\mathrm{H}_{2}$ üretimi de dahil olmak üzere, fotokatalitik uygulamalar için kapsamlı olarak incelenmiştir (Gupta ve Tripathi, 2011). Uygun konsantrasyonlarda Ti-NP’lerin yapraktan uygulanmasının, bitki fotosentezinin ve ilgili fizyolojik etkinliklerini arttırarak bitki büyümesini teşvik edebileceği ortaya konmuştur. Bununla birlikte, bitki büyümesinin iyileştirilmesinde Ti-NP'lerin saf kimyasal reaksiyonlarının (foto-kataliz) bitkinin biyokimyasal süreçleri ile nasıl koordine olduğunu veya olmadığını gösteren ayrıntılı çalışmalar veya kanıtlara ihtiyaç vardır. Tohum çimlenmesi üzerine de Ti-NP’lerin negatif etkileri bildirilmiştir (Castiglione ve ark., 2011). 


\subsection{Nanopartiküler Boyutta Kapsüllenmiş Karbon Materyalleri (CNT)}

Yapılan bazı çalışmalarda düşük dozlarda CNT'lerin tohum çimlenmesi ve bitki büyümesini uyarabileceği belirtilmiştir. Lin ve Xing (2007), $2 \mathrm{~g} \mathrm{~L}^{-1}$ olacak şekilde çok katmanl CNT'lerin uygulamasının mısırın çimlendirilmiş tohumlarının 5 günlük inkübasyonu ile kök uzunluğunu kontrole kıyasla arttırdığını bildirmişlerdir. Ancak, turp, marul veya salatalık tohumlarında hiçbir olumlu sonuç alınmazken benzer şekilde, çimlenmiş soğan (Allium cepa) ve hıyar (Cucumis sativus) tohumlarının kök büyümesi, 48 saatlik bir inkünasyon süresince $0.16,0.9$ ve $5 \mathrm{~g} \mathrm{~L}^{-1}$ 'de (Canas ve ark., 2008) tek duvarl1 CNT'lere maruz bırakılması sonucu arttırdığ 1 gözlemlenmiştir. Bununla birlikte, aynı koşullar altında, CNT'ler lahana tohumları (Brassica oleracea) veya havuç (Daucus sativus) üzerinde önemsiz etkilere sahipken çimlendirilmiş domates tohumlarının kök gelişimini engellediği bildirilmiştir. Daha yakın zamanlarda, her iki tip CNT'nin de tohum çimlenme yüzdesini arttırdığı domates, soya fasulyesi ve mısırın fide büyümesini arttırdığını bildirmişlerdir (Khodakovskaya ve ark., 2013; Lahiani ve ark., 2013; Villagarcia ve ark., 2012). Örneğin, Khodakovskaya ve ark. (2013) tarafından yapılan bir çalışmada, suya ve aktif karbon uygulamasına karşılık gelen kontrollere tabi tutulanların her ikisine kıyasla, $50 \mathrm{mg}$ $\mathrm{L}^{-1}$ CNT'lerin uygulanmasının domates verimini iki kat arttırdığını bildirmişlerdir. Yazarlar, domates bitkilerinde su kanal proteinlerinin ekspresyonunu ve büyümesini hızlandırmak (Hodakovskaya ve ark., 2013; Villagarcia ve ark., 2012), dolayısıyla bitki su alımını ve kullanım verimliliğini arttırmak için, CNT kullanılmasını önermişlerdir. CNT’lerin bitkiler üzerindeki büyüme uyarıcı işlev görmesi konusunda önemli ve umut verici bir yaklaşım olduğu bildirilmiştir. Bu CNT'lerin soya fasulyesi ve mısır gibi önemli bazı tarla bitkilerinin verimleri üzerindeki etkilerini incelemek için daha fazla alan araştırması yapılması gerekmektedir (Khodakovskaya ve ark., 2013).

Genel olarak bakacak olursak, bitkilerde tek duvarlı karbon nanotüpler (SWCNT'ler) ve çok duvarlı karbon nanotüpler (MWCNT'ler) bitkinin çeşitli fizyoloji ve biyokimyasını etkiler. Tek duvarlı karbon nanotüpleri (SWCNT’ler), kök gelişimini bitkinin türüne bağımlı olacak bir şekilde etkiler (Canas ve ark., 2008). Khodakovskaya ve ark. (2013) tarafından yapılan bir araştırmada, karbon bazlı tüm nanopartiküllerin, bitki genlerinin ekspresyon düzeyini potansiyel olarak değiştirebileceğine işaret etmiştir. Örneğin, SWCNT'ler domateslerde stres tepkilerine katılan genlerin ekspresyonunu etkiler, bu da bitki gelişimini kontrol etmek için kontrol edilebilir bir özelliktir (Lahiani ve ark., 2015). Karbon tabanlı NM'ler tarafindan indüklenen misır (Zea mays) hücre duvar matrisinde katyonik değişim biyokimyasal değişiklikler gibi bazı iyonlarda redoks modifikasyonlarını etkiler (Tiwari ve ark., 2014).

\subsection{Nanopartiküler Besin Elementlerinin Bitki Bünyesine Alınımı ve Kullanım Alanları}

Bitki sistemlerinde nanopartiküler olmayan besin elementleri gibi, NP'lerin alınması ve taşınması için de iki doğrulanmış yol vardır: kökten yaprak-meyvelere veya yapraktan-köklere doğru taşınmadır (Ma ve ark., 2015a). Şekil 2'de gösterildiği gibi, bir taraftan, kökten yaprak-meyve yoluna yapılan çalışmalar, hidrofonik (Hernandez-Viezcas ve ark., 2016) ya da toprak kültürü (Rico ve ark., 2015a) yöntemleri yoluyla gerçekleştirilir ve bildirilen NP'lerin translokasyonu fideler (Servin ve ark., 2012) veya olgun yumrulardan başlar (Ghodake ve ark., 2011). Yapılan bazı çalışmalarda, NP'lerin apoplastik yollarla kökün endodermisi tarafindan absorbe edilebileceğini ve daha sonra simplastik yollarla vasküler silindire transfer edilebileceğini göstermektedir (Zhao ve ark., 2012b).

NP'lerin bitki kökünden, yaprağa veya meyveye yer değiştirmesi, ksilem veya filoem yoluyla oluşabilir (Hernandez-Viezcas ve ark., 2013; Servin ve ark., 2013; Zhao ve ark., 2014). Öte yandan, yapraktan köke doğru olan yollar, NP'lerin stoma yoluyla nüfuz etmesini veya NP'lerin sıkışmasını kapsar ve saplara yeniden dağılır (Hong ve ark., 2014; Larue ve ark.,, 2014). NP'lerin bitkiye alımında, her iki yolda araştırmacılar tarafından fizyolojik parametreler (çimlenme oranı, uzama ve su içeriği gibi), antioksidan aktiviteleri (enzimler, $\mathrm{H}_{2} \mathrm{O}_{2}$ seviyesi ve lipid peroksidasyonu gibi), tarımsal parametreleri mikro-makro element değerleri, gıda kalitesi ve fotosentetik parametreler (klorofil içeriği, kloroplast sayısı ve fotosentetik oran gibi) olarak değerlendirilmiş ve farklıklar gözlemlenmiştir. 


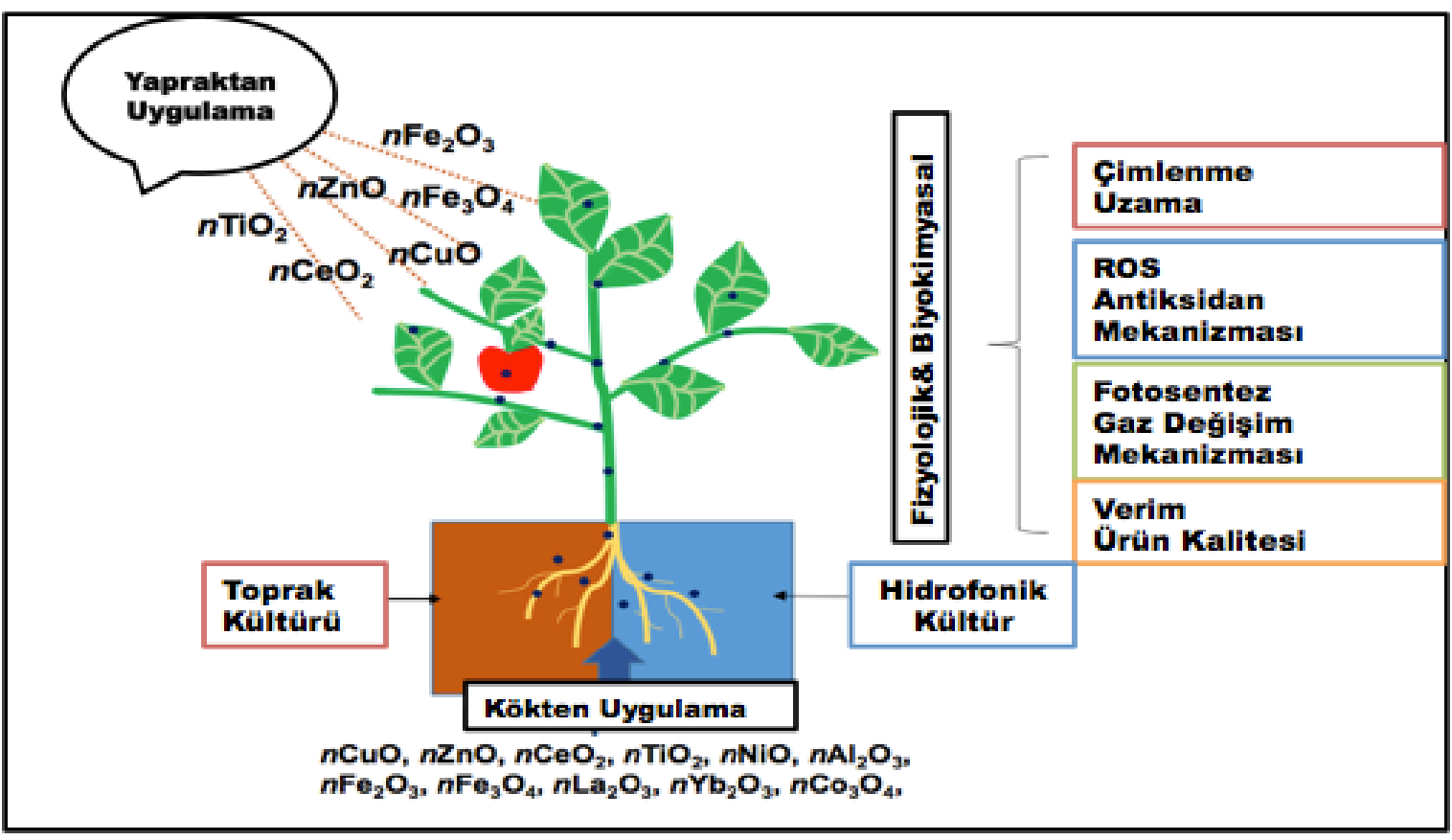

Şekil 2. Farklı ortam ve uygulamaların nanopartiküllerin taşınımı konusunda bitkinin fiziksel ve biyokimyasal içerikleri üzerine etkisi (Zhao ve ark., 2012b).

NP'lerin bitki dokularındaki birikimi hakkında, iletim elektron mikroskopisi (TEM) (Du ve ark., 2011), taramalı elektron mikroskopisi-SEM (Bandyopadhyay ve ark., 2015), konfokal mikroskobi (Xanes) yakınında X-1şını emilimi(Hernandez-Viezcas ve ark., 2012b), iki foton uyarım mikroskobu (Wild ve Jones, 2009), mX-ışını flüoresansı (Servin ve ark., 2013) ve uzatılmış X-1şını emme ince yapısı (Lv ve ark., 2015) ve diğer teknikler kullanılarak bilgiler vermişlerdir.

Şekil 3' de görüldüğ̈̈ gibi sonuçlar, ZnO-NP'ler topraktaki inkübasyondan bir saatlik periyot boyunca nano-formda tespit edilmemiştir. Nano-ZnO ve nano-CuO nano-partiküllerinin formunu muhafaza etmek yerine çözünür tuzlara biyotransformasyon yaptığını göstermiştir. Börülce (Vigna unguiculata) (Wang ve ark., 2013a), buğday (Triticum aestivum) soya fasulyesi (Glisin max) (Hernandez-Viezcas ve ark., 2013) ve misır (Zea mays) dokuları ile (Lv ve ark., 2015) benzer bir etki gözlemlenmiştir.

Bitkilerle temas halinde olan nanopartiküller Şekil 4'deki gibi kök epidermisinin hücre duvarına ve hücre zarına nüfuz eder. Bitki vasküler demetine (ksilem) girmek için karmaşık bir olaylar dizisiyle stelize yapraklara translokasyon yapmak üzere simplastiğe geçer. Bununla birlikte, bozulmamış hücre zarını geçmek için NP, hücre zarındaki gözeneklerle hareket eder ve bu da, nanomateryalin alınımının boyuta özel olduğunu gösterir (Ma ve ark., 2010a, 2010b; Rico ve ark., 2011). NP’ler stele ulaşmadan önce endodermis apoplast1 yoluyla pasif olarak entegre edilir . 


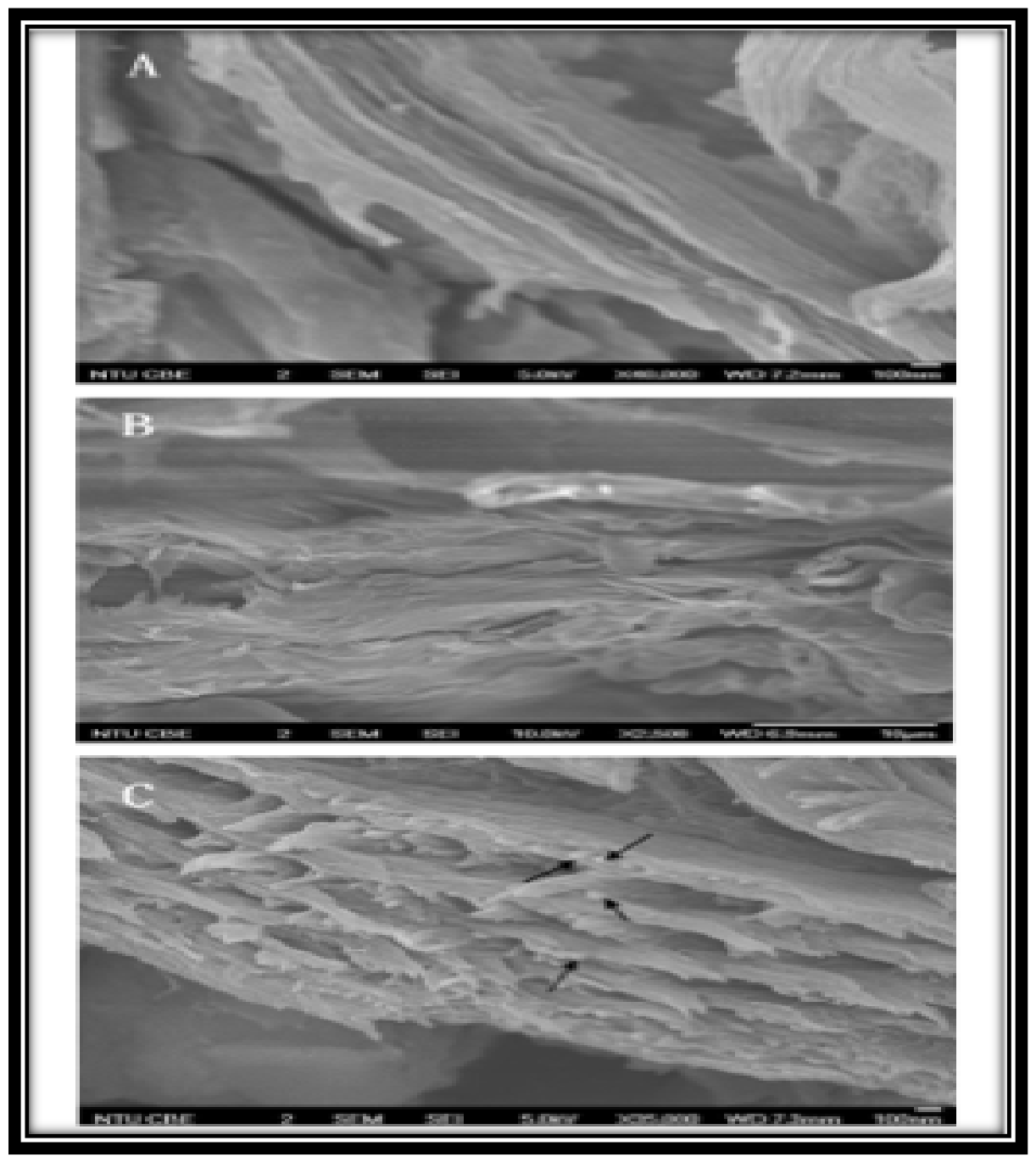

Şekil 3. S. tabernaemontani kök yüzeyindeki ZnO NP’ler, $\mathrm{Zn}^{2+}$ iyon birikiminin SEM görüntüleri (A) kontrol; (B) $1.000 \mathrm{mg} \mathrm{Zn}^{2+} \mathrm{L}^{-1}$ ve (C) $1.000 \mathrm{mg} \mathrm{ZnO}$ NP'ler $\mathrm{L}^{-1}$ (Bandyopadhyay ve ark., 2015).

Ksilem, nanopartiküllerin dağılımı ve translokasyonunda en önemli araçtır. NP’lerin alınım mekanizması, genel olarak, sinyal verme, geri dönüşüm ve plazma zarının regülasyonu gibi birkaç hücresel işlemi içeren bir aktif aktarım mekanizması olarak düşünülür. Birçok çalışmada, bitki hücre duvarının yalnızca seçilen nano parçacıkların gözeneklerden geçmesini kolaylaştıran yarı geçirgen bir bariyer gibi davrandığı gözlenmiştir (Lin ve ark., 2009a-2009b; Chen ve ark., 2003). Nanopartikülün hücre içine girişi, hücre süspansiyonu ortamında farklılaşır. Burada, vakuoldaki endositoz, plazma zarından oluşan vesiküller yoluyla apoplast yoluyla olur (Chen ve ark., 2003). Örneğin, yonca (Medicago sativa) hücrelerinde, nanopartiküllerin (CdSe/ZnS) birikimi, özellikle sitoplazmada ve çekirdekte meydana gelir. Tohumda, nanopartiküller sıvı solüsyonun kotiledona difüzyonuna yardımc1 olan parenkimal hücreler arası boşluklardan geçebilir (Van Dongen ve ark., 2003; Lee ve ark., 2010; Ma ve ark., 2010a,b). Lee ve ark. (2010), $\mathrm{SiO}_{2} \mathrm{NP}$ 'lerin ve $\mathrm{Al}_{2} \mathrm{O}_{2} \mathrm{NP}$ 'lerin Fare Kulağ1 Teresi'nin (Arabidinopsis thalian) çimlenmesini ve büyümesini etkilemediğini, ZnONP'lerin çimlenmesini engellediğini öne sürmüşlerdir. Çekirdekte, nanoparçacıkların girişini düzenleyen başka bir yapı akuaporin varlığı gözlemlenmiştir (Khodakovskaya ve ark., 2009). Hidroelektrik iletkenlik farkı, hücre duvarı gözenek boyutu vb. gibi bitki türleri arasındaki çeşitli fiziko-kimyasal değişimler, nanoparçacıkların taşınması ve birikimine etki edebilir. Son zamanlarda, molekül/iyon toplama ve translokasyon kinetiğinin anlaşılmasında çok ilerleme kaydedilmiş ve üretilen NP'lerin bu toplama, translokasyon ve aglomerasyon kinetiğini izlemek için genişletilebilmiştir. NM'lerin alımının ve translokasyonunun şekil, boyut ve kompozisyona bağlı olduğu görülmektedir. 


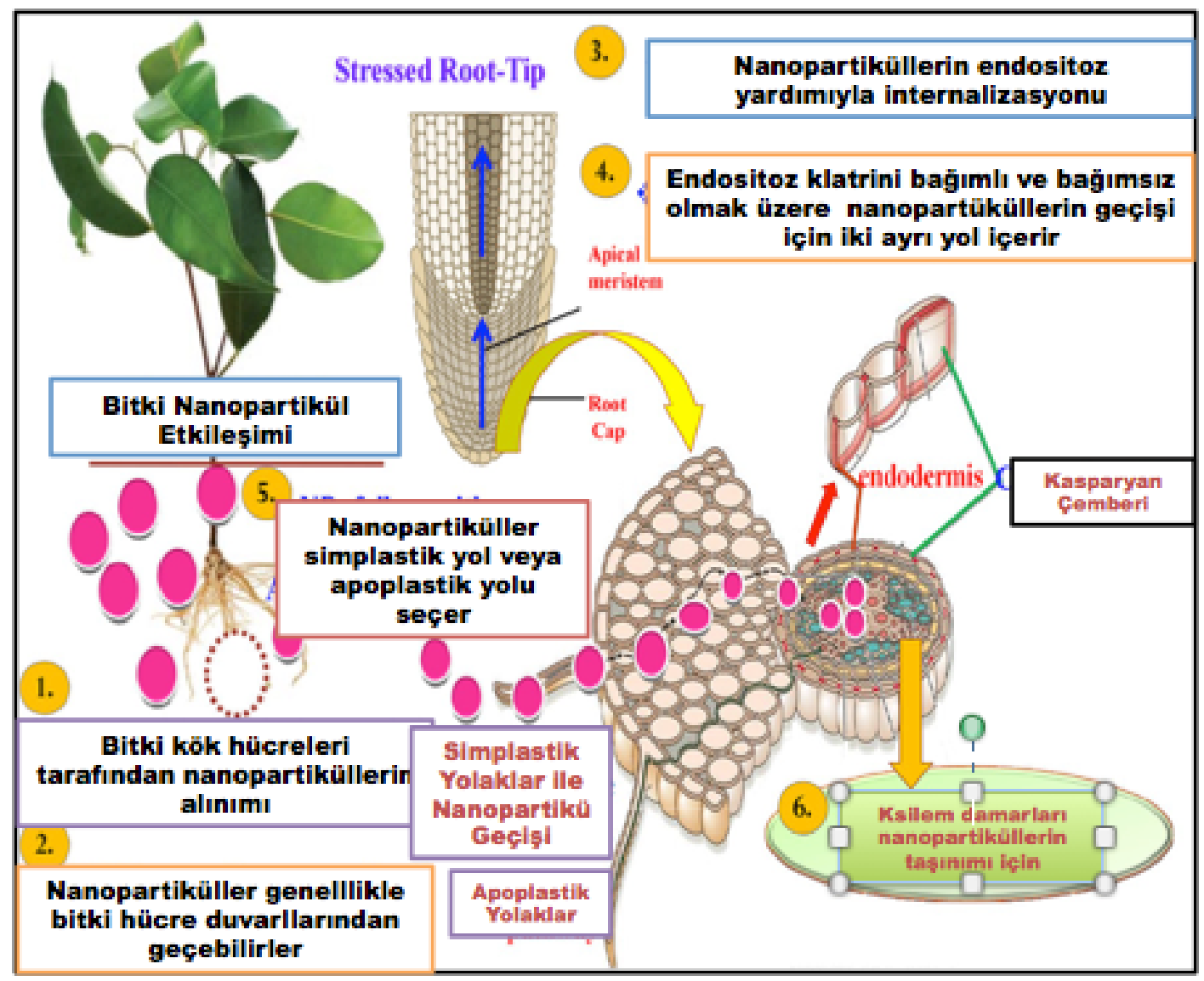

Şekil 4. Kökleri vasıtasıyla nanopartiküllerin bitki bünyesine alım süresince oluşan akış şeması (Ma ve ark., 2010a).

\subsection{Farklı Dozlarda Uygulanan Nanomateryallerin Bitkiler Üzerinde Kritik Toksik Etkileri}

Raliya ve ark. (2015), ZnO ( $<50 \mathrm{~nm}$ ) nanopartiküllerini domates bitkisine 10, 100, 250, 500, 750, $1.000 \mathrm{mg} \mathrm{L}^{-1}$ olacak şekilde topraktan uygulama yapmışlar, 66 gün süren deneme sonucunda $750 \mathrm{mg} \mathrm{L}^{-}$ ${ }^{1}$ 'ye kadar olan dozlarda çimlenme, kök gelişimi ve toprak üstü aksamlarının gelişiminin kontrole göre arttığını gözlemlemişlerdir. Fakat $1.000 \mathrm{mg} \mathrm{L}^{-1}$ 'de kök gelişimi, çimlenme ve toprak üstü akşamların gelişiminin kontrole göre olumsuz etkilendiğini bildirmişlerdir.

Mukherjee ve ark. (2014), ZnO (<10 nm) nanopartiküllerini 125, 250, $500 \mathrm{mg} \mathrm{L}^{-1}$ olacak şekilde yeşil bezelyeye topraktan uygulayarak 25 günlük süre sonucunda $500 \mathrm{mg} \mathrm{L}^{-1}$ uygulamasının klorofil içeriğini \% 77 oranında azalttığını gözlemlemişlerdir.

Lee ve ark. (2013a), $\mathrm{ZnO}(<50 \mathrm{~nm})$ ve $\mathrm{CuO}$ nanopartikülleri karışımını 50, 500, 2.000, $4.000 \mathrm{mg} \mathrm{L}^{-}$ ${ }^{1}$ olacak şekilde karabuğday köklerine uygulamış, 7 günlük süre sonucunda 2.000 ve $4.000 \mathrm{mg} \mathrm{L}^{-1}$ uygulamasının kök uzunluğunu ve biyokütlesini azalttığını gözlemlemişlerdir.

Servin ve ark. (2013), $\mathrm{TiO}_{2}(<27 \mathrm{~nm})$ nanopartikülleri 250, 500, $750 \mathrm{mg} \mathrm{L}^{-1}$ olacak şekilde bibere topraktan uygulamışlar ve 90 günlük sürede CAT aktivitesinin arttığını, $500 \mathrm{mg} \mathrm{L}^{-1}$ uygulamasının APX aktivitesini azalttığını gözlemlemiştir.

\section{Sonuç ve Öneriler}

Bitkiler için öneme sahip olan bitki besin elementlerinin bitkilerce alınım formlarının nanomateryal şeklinde uygulanması ile bitkinin ihtiyacı olan besin elementlerinden maksimum düzeyde istifade edebileceği öngörülmektedir. Nanomalzemelerin geniş spesifik yüzey alanları sayesinde toprak kolloidleri tarafından tutunma potansiyelleri artarak, yıkanıp uzaklaşma riskinin de düşürüleceği öngörülmektedir. En önemli faktörlerden biri de konvansiyonel gübrelerin maliyeti ve aşırı dozda uygulanması çevresel risk potansiyeli oluşturmaktadır. Fakat nanomateryallerin bu gübrelere göre daha 
düşük miktarda kullanımları ile hem maliyetlerin düşmesine hem de risk etmenlerinin minimize edilmesine neden olacaktır. Nanomalzemeler içerisine kapsüllenmiş elementler bitkiye direk kayba maruz kalmadan ulaşacaktır.

Tüm bu bilgilerin işığında günümüz teknolojisinden faydalanarak doğru ve ilkeli modelleri tarıma entegre etmek biz bilim insanlarının en büyük sorumluluğudur. Bu derleme makale henüz bakir olan bu alanda çalışmak isteyen ve çalışmış olan bilim insanlarına ışık tutacak ve düşünce altyapısı oluşturacak potansiyele sahiptir.

\section{Kaynakça}

Ahmad M.A., Nida S., Monther M. T., (2019). Effect of Nano Technology in Combination with Soil Solarization to Control Panama Disease of Banana in Jordan Valley. Yüz.Yıl Üni.Tar. Bil. Der. 29 / (May1s 2019): 16-23 . https://doi.org/10.29133/yyutbd.466531.

Bandyopadhyay, S., Plascencia-Villa, G., Mukherjee, A., Rico, C.M., Jose -Yacama n, M., PeraltaVidea, J.R., \& Gardea-Torresdey, J.L. (2015). Comparative phytotoxicity of ZnO NPs, bulk $\mathrm{ZnO}$, and ionic zinc onto the alfalfa plants symbiotically associated with Sinorhizobium meliloti in soil. Sci. Total Environ., 515-516, 60-69.

Batsmanova, L.M, Taran, N.Y., Gonchar, O.M., Lopatko, K.G.,., Patyka, M.V., \& Volkogon, M.V. (2014). The effect of colloidal solution of molybdenum nanoparticles on the microbial composition in rhizosphere of Cicer arietinum L. Nanoscale Res. Lett.9, 289.

Batsmanova, L.M., Gonchar, L.M., Taran, N.Y., \& Okanenko, A.A. (2013). Using a colloidal solution of metal nanoparticles as micronutrient fertilizer for cereals. Proceedings of the International Conference Nanomaterials: Applications and Properties.

Castiglione, M.R., Giorgetti, L., Geri, C., \& Cremonini, R. (2011). The effects of nano-TiO2 on seed germination, development and mitosis of root tip cells of Vicia narbonensis L. and Zea mays L. J. Nanoparticle Res. 13, 2443-2449.

Chen, W.S. (1991). Changes in cytokinins before and during early flower bud differentitation in lychee (Litchi chinensis Sonn.). Plant Physiology, 96, 1203- 1206.

Dağhan, H. (2017). Nano-Gübreler. Turk J Agric Res., 4(2), 197-203

Delfani, M., Firouzabadi, M.B., Farrokhi, N., \& Makarian, H. (2014). Some physiological responses of black-eyed pea to iron and magnesium nanofertilizers. Commun. Soil Sci. Plant Anal. 45, 530540.

Du, W.C., Sun, Y.Y., Ji, R., Zhu, J.G., Wu, J.C., \& Guo, H.Y. (2011). TiO2 and ZnO nanoparticles negatively affect wheat growth and soil enzyme activities in agricultural soil. J. Environ. Monit. 13 (4), 822-828.

Gao, F., Liu, C., Qu, C., Zheng, L., Yang, F., Su, M., et al. (2008). Was improvement of spinach growth by nano-TiO2 treatment related to the changes of Rubisco activase? Biometals 21, 211-217.

Ghafariyan, M.H., Malakouti, M.J., Dadpour, M.R., Stroeve, P., \& Mahmoudi, M. (2013). Effects of magnetite nanoparticles on soybean chlorophyll. Environ. Sci. Technol. 47, 10645-10652.

Ghodake, G., Seo, Y.D., \& Lee, D.S. (2011). Hazardous phytotoxic nature of cobalt and zinc oxide nanoparticles assessed using Allium cepa. J. Hazard. Mater. 186, 952-955.

Güneş, A., Alpaslan, M., \& İnal, A., (2007). Bitki Besleme ve Gübreleme. Ankara Üniv., Ziraat Fak. Ders Kitabı, Ankara Üniv. Basımevi, Ankara.

Gupta, S.M., \& Tripathi, M. (2011). A review of $\mathrm{TiO}_{2}$ nanoparticles. Chin. Sci. Bull. 56, 1639-1657.

Hernandez-Viezcas, J.A., Castillo-Michel, H., Andrews, J.C., Cotte, M., Rico, C., Peralta- Videa, J.R. \& Gardea-Torresdey, J.L. (2013). In situ synchrotron X-ray fluorescence mapping and speciation of $\mathrm{CeO} 2$ and $\mathrm{ZnO}$ nanoparticles in soil cultivated soy- bean (Glycine max). ACS Nano 7, 1415-1423.

Hershey, D.R., Paul, J.L., \& Carlson, R.M., (1980). Evaluation of potassium-enriched clinoptilolite as a potassium source for potting media. HortSci. 15, 87-89.

Hong, J., Peralta-Videa, J.R., Rico, C., Sahi, S., Viveros, M.N., Bartonjo, J., Zhao, L.J., \& GardeaTorresdey, J.L. (2014). Evidence of translocation and physiological im- pacts of foliar applied $\mathrm{CeO} 2$ nanoparticles on cucumber (Cucumis sativus) plants. Environ. Sci. Technol. 48, 43764385. 
Khodakovskaya, M.V., de Silva, K., Nedosekin, D.A., Dervishi, E., Biris, A.S., Shashkov, E.V., Galanzha, E.I., \& Zharov, V.P. (2011). Complex genetic, photothermal, and photoacoustic analysis of nanoparticle-plant interactions. Proc. Natl. Acad. Sci. 108 (3), 1028-1033.

Lahiani, M.H., Chen, J., Irin, F., Puretzky, A.A., Green, M.J. \& Khodakovskaya, M.V. (2015). Interaction of carbon nanohorns with plants: uptake and biological effects. Carbon 81, 607e619.

Lee, W., An, Y., Yoon, H., \& Kweon, H. (2008). Toxicity and bioavailability of copper nanopar- ticles to the terrestrial plants mung bean (Phaseolus radiatus) and wheat (Triticum aestivum): plant agar test for water-insoluble nanoparticles. Environ. Toxicol. Chem. 27, 1915-1921.

Lin, D., \& Xing, B. (2007). Phytotoxicity of nanoparticles: inhibition of seed germination and root growth. Environ. Pollut. 150, 243-250.

Lin, D., \& Xing, B. (2008). Root uptake and phytotoxicity of ZnO nanoparticles. Environ. Sci. Technol. 42, 5580-5585.

Liu, R., \& Lal, R., 2014. Synthetic apatite nanoparticles as a phosphorus fertilizer for soybean (Glycine max). Sci. Rep. 4, 5686-5691.

Liu, R., Zhang, H., \& Lal, R. (2016). Effects of stabilized nanoparticles of copper, zinc, manganese, and iron oxides in low concentrations on lettuce (Lactuca sativa) seed germination: nanotoxicants or nanonutrients? Water Air Soil Pollut., 227, 42.

Liu, X., Zhang, D., Zhang, S., He, X., Wang, Y., Feng, Z., et al. (2005). Responses of peanut to nanocalcium carbonate. J. Plant. Nutr. Fert. (Chin.) 11, 385-389.

Liu, Y., Laks, P., \& Heiden, P. (2002). Controlled release of biocides in solid wood. I. Efficacy against brown rot wood decay fungus (Gloeophyllum trabeum). J. Appl. Polym. Sci. 86, 596-607.

Lopez-Moreno, Hernandez-Viezcas, J.A., Castillo-Michel, H.A., M., Peralta-Videa, J.R., \& GardeaTorresdey, J.L. (2016). Interactions between $\mathrm{CeO} 2$ nanoparticles and the desert plant mesquite: a spectroscopy approach. ACS Sustain. Chem. Eng. 4 (3), 1187-1192.

Lv, J., Zhang, S., Luo, L., Zhang, J., Yang, K., Christie, P. (2015). Accumulation, speciation and uptake pathway of ZnO nanoparticles in maize. Environ. Sci. Nano 2, 68-77.

Ma, C.X., White, J.C., Dhankher, O.P., \& Xing, B. (2015a). Metal-based nanotoxicity and detoxification pathways in higher plants. Environ. Sci. Technol. 49 (12), 7109-7122.

MacKown, C.T. \& Tucker, T.C. (1985). Ammonium nitrogen movement in a coarse-textured soil amended with zeolite. Soil Sci. Soc. Am. J. 49, 235-238.

Mahajan, P., Dhoke, S.K. \& Khanna, A.S. (2011). Effect of Nano-Zno Particle Suspension on Growth of Mung (Vigna radiata) and Gram (Cicer arietinum) Seedlings Using Plant Agar Method. J. Nanotechnol. 7 pp (Article ID 696535).

Malekian, R., Abedi-Koupai, J., \& Eslamian, S.S. (2011). Influences of clinoptilolite and surfactantmodified clinoptilolite zeolite on nitrate leaching and plant growth. J. Hazard. Mater., 185: 970976.

Ming, D.W., \& Allen, E.R. (2001). Use of Natural Zeolites in Agronomy, Horticulture, and Environmental Soil Remediation. In: Bish, D.L., Ming, D.W. (Eds.), Natural Zeolites: Occurrence, Properties, Applications vol. 45. Mineralogical Soc. Am., Chantilly, pp. 619-654.

Mukherjee, A., Peralta-Videa, J.R., Bandyopadhyay, S., Rico, C.M., Zhao, L., \& Gardea- Torresdey, J.L., (2014). Physiological effects of nanoparticulate $\mathrm{ZnO}$ in green peas (Pisum sativum L.) cultivated in soil. Metallomics 6, 132-138.

Mukherjee, A., Sinha, I., \& Das, R. (2015). Application of nanotechnology in agriculture: Future prospects. Outstanding Young Chemical Engineers (OYCE) Conference, March 13-14, DJ Sanghvi College of Engineering, Mumbai, India.

Musante, C. \& White, J.C. (2012). Toxicity of silver and copper to Cucurbita pepo: differential effects of nano and bulk-size particles. Environ. Toxicol. 27, 510-517.

Naderi, M., Danesh Shahraki, A.A., \& Naderi, R. (2011). Application of nanotechnology in the optimization of formulation of chemical fertilizers. Iran J. Nanotech. 12, 16-23.

Nair, R., Varghese, S.H., Nair, B.G., Maekawa, T., Yoshida, Y. \& Kumar, D.S. (2010). Nanoparticulate material delivery to plants. Plant Sci. 179, 154-163.

Nekrasova, G.F., Ushakova, O.S., Ermakov, A.E., Uimin, M.A. \& Byzov, I.V. (2011). Effects of copper(II) ions and copper oxide nanoparticles on Elodea densa Planch. Russ. J. Ecol. 42, 458463. 
Pradhan, S., Patra, P., Das, S., Chandra, S., Mitra, S., Dey-Kumar, K., Akbar, S., Palit, P. \& Goswami, A. (2013). Photochemical Modulation of Biosafe Manganese Nanoparticles on Vigna radiata: A Detailed Molecular, Biochemical, and Biophysical Study. Environ. Sci. Technol. 4722 1312213131

Raikova, O.P., Panichkin, L.A., \& Raikova, N.N. (2006). Studies on the Effect of Ultrafine Metal Powders Produced by Different Methods on Plant Growth and Development. Nanotechnologies and Information Technologies in the 21st Century. Proceedings of the International Scientific and Practical Conference, 108-111.

Raliya, R., Nair, R., Chavalmane, S., Wang, W.N., \& Biswas, P. (2015). Mechanistic evaluation of translocation and physiological impact of titanium dioxide and zinc oxide nanoparticles on the tomato (Solanum lycopersicum L.) plant. Metallomics 7, 1584e1594.

Reynolds, G.H. (2002). Forward to the future nanotechnology and regulatory policy. Pac. Res. Inst. 24, $1-23$.

Rico, C.M., Majumdar, S., Duarte-Gardea, M., Peralta-Videa, J.R., \& Gardea- Torresdey, J.L. (2011). Interaction of nanoparticles with edible plants and their possible implications in the food chain. J. Agric. Food Chem. 59, 3485-3498.

Rico, C.M., Peralta-Videa, J.R., Gardea-Torresdey, J.L., 2015b. Chemistry, biochemistry of nanoparticles, and their role in antioxidant defense system in plants. Nanotechnol. Plant Sci. 117. Springer International Publishing.

Roco, M.C. (2003). Nanotechnology: convergence with modern biology and medicine. Curr. Opin. Biotechnol. 14, 337e346.

Scott, N., \& Chen, H. (2003). Nanoscale Science and Engineering for Agriculture and Food Systems. A Report Submitted to Cooperative State Research, Education and Extension Service. USDA. National Planing Workshop, Washington.

Selivanov, V.N., Zorin, E.V., 2001. Sustained Action of ultrafine metal powders on seeds of grain crops. Perspekt. Materialy 4, 66-69.

Servin, A., Elmer, W., Mukherjee, A., De La TorreRoche, R., Hamdi, H., White, J.C., Bindraban, P., \& Dimkpa, C. (2015). A review of the use of engineered nanomaterials to suppress plant disease and enhance crop yield. Journal of Nanoparticle Research, 17, 92-113.

Servin, A.D., Morales, M.I., Castillo-Michel, H., Hernandez-Viezcas, J.A., Munoz, B., Zhao, L.J., Nunez, J.E., Peralta-Videa, J.R. \& Gardea-Torresdey, J.L. (2013). Synchrotron verification of $\mathrm{TiO} 2$ accumulation in cucumber fruit: a possible pathway of $\mathrm{TiO} 2$ nanoparticle transfer from soil into the food chain. Environ. Sci. Technol. 47 (20), 11592e11598.

Shah, V., \& Belozerova, I. (2009). Influence of metal nanoparticles on the soil microbial com- munity and germination of lettuce seeds. Water Air Soil Pollut.197, 143-148.

Singh, M.D., Chirag, G., Prakash, P.O., Mohan, M.H.,Prakasha, G., \& Vishwajith, (2017). Nano fertilizers is anew way to increase nutrients use efficiency in cropproduction. International Journal of Agriculture Sciences, 9(7), 3831-3833.

Sohrab, D., Tehranifara, A., Davarynejada, G., Abadíab, J., Khorasani, R., Effects of foliar applications of zinc and boron nano-fertilizers on pomegranate (Punica granatum cv. Ardestani) fruit yield and quality. Scientia Horticulturae, 210 (2016), 57-64

Song, G., Gao, Y., Wu, H., Hou, W., Zhang, C., \& Ma, H. (2012). Physiological effect of anatase TiO2 nanoparticles on Lemna minor. Environ. Toxicol. Chem. 31, 2147-2152.

Stampoulis, D., Sinha, S.K., White, J.C. (2009). Assay-dependent phytotoxicity of nanoparti- cles to plants. Environ. Sci. Technol. 43, 9473-9479.

Su, M., Liu, H., Liu, C., Qu, C., Zheng, L., \& Hong, F. (2009). Promotion of nano-anatase TiO2 on the spectral responses and photochemical activities of D1/D2/Cyt b559 complex of spinach. Spectrochim. Acta A 72, 1112-1116.

Subramanian, K.S., Manikandan, A., Thirunavukkarasu, M., \& Sharmila Rahale, C. (2015). NanoFertilizers for Balanced Crop Nutrition. In: Rai, M., Ribeiro, C., Mattoso, L., Duran, N. (Eds.), Nanotechnologies in Food and Agriculture. Springer Int. Publishing, Switzerland, pp. 69-80.

Tiwari, D.K., Dasgupta-Schubert, N., Villasen or-Cendejas, L.M., Villegas, J., Carreto- Montoya, L., Borjas-Garcia, S.E. (2014). Interfacing carbon nanotubes (CNT) with plants: enhancement of growth, water and ionic nutrient uptake in maize (Zea mays) and implications for nanoagriculture. Appl. Nanosci. (4), 577-591. 
Wang, P., Menzies, N.W., Lombi, E., McKenna, B.A., Johannessen, B., Glover, C.J., Kappen, P., Kopittke, P.M. (2013a). Fate of ZnO nanoparticles in soils and cowpea (Vigna unguiculata). Environ. Sci. Technol. 47, 13822e13830.

Wiesner, M.R., Lowry, G.V., Alvarez, P., Dionysion, D. \& Biswas, P. (2006). Assessing the risks of manufactured nanomaterials. Environ. Sci. Technol. 40, 4336-4345.

Wild, E., \& Jones, K.C. (2009). Novel method for the direct visualization of in vivo nanomaterials and chemical interactions in plants. Environ. Sci. Technol. 43, 5290-5294.

Yang, F., Liu, C., Gao, F., Su, M., Wu, X., Zheng, L., et al. (2007). The improvement of spinach growth by nano-anatase $\mathrm{TiO} 2$ treatment is related to nitrogen photoreduction. Biol. Trace Elem. Res. 119, 77-88.

Zhao, L., Peralta-Videa, J.R., Rico, C.M., Hernandez-Viezcas, J.A., Sun, Y., Niu, G., et al. (2014). CeO2 and $\mathrm{ZnO}$ nanoparticles change the nutritional qualities of cucumber (Cucumis sativus). J. Agric. Food Chem. 62, 2752-2759.

Zhao, L.J., Peralta-Videa, J.R., Ren, M., Varela-Ramirez, A., Li, C., Hernandez- Viezcas, J.A., Aguilerad, R.J. \& Gardea-Torresdeya, J.L., (2012b.) Transport of Zn in a sandy loam soil treated with $\mathrm{ZnO}$ NPs and uptake by corn plants: electron microprobe and confocal microscopy studies. Chem. Eng. J. 184, 1-8. 